\title{
A ESCRITA PERFORMÁTICA DE AL BERTO: À PROCURA DO VENTO NUM JARDIM D'AGOSTO (1977)
}

\author{
AL BERTO'S PERFORMATIVE WRITING: \\ À PROCURA DO VENTO NUM JARDIM \\ D'AGOSTO (1977)
}

Gustavo Cerqueira Guimarães ${ }^{1}$

\begin{abstract}
RESUMO
Este trabalho investiga alguns elementos concernentes ao gênero literário em Al Berto (1948-1997), propondo uma análise acerca de sua escrita em À procura do vento num jardim d'agosto (1977) e como ela se desdobra em questões frequentemente problematizadas na literatura contemporânea, tais como a hibridação de gênero, o próprio fazer literário (e seus paratextos), a relação entre vida e obra, a escrita performática e a criação do nome de autor - Al Berto. A opção por analisar uma única obra tem o objetivo de facilitar a compreensão do funcionamento geral da produção do artista, tendo em vista que se encontram ressonâncias marcantes desse livro ao longo da trajetória do autor.
\end{abstract}

PALAVRAS-CHAVE: Al Berto; Literatura portuguesa; Escrita performática; Edição.

\section{ABSTRACT}

This work investigates some elements some elements concerning by literary genre in Al Berto (1948-1997), proposing an analysis about writing in À procura do vento num jardim d'agosto (1977) and how it unfolds in questions frequently problematized in contemporary, as the hybridization of genre, literary making itself (and its paratexts), the relation between life and work, performance writing and the creation of the authorship name. The option to analyze a single work has the objective of facilitating an understanding of the general functioning of the artist's production, since the book resonates throughout the author's trajectory.

KEYWORDS: Al Berto; Portuguese literature; Performative writing; Edition. 
Decido escrever um romance. Personagens: a

Grande Escritora de Grandes Olhos Pardos, mulher farpada e apaixonada. O fotógrafo feio e fino que me vê pronta e prosa de lápis comprido inventando a ilha perdida do prazer.

Ana Cristina Cesar

o quarto povoa-se de corpos nascidos duma mancha de tinta.

Al Berto

Joaquim Manuel Magalhães, crítico e poeta português, afirma que, no contexto literário português dos anos de ditadura, mais especificamente dos anos 1970, não chegariam a seu país grandes obras dos escritores exilados, cabendo esse feito aos textos de caráter ensaístico, sobretudo no domínio da História, pois,

[...] no campo restrito da produção literária, mais uma vez a esperança se ficou pelo desalento. Que me lembre [...] pelo menos dentre os autores mais novos que voltaram, apenas referia a ousadia moral da tentativa entre a ficção e a reportagem de Sérgio da Costa e Silva [... e] o fluxo confessional, onírico e insurrecional de Al Berto, [em] À procura do vento num jardim d’agosto (MAGALHÃES, 1981, p. 254).

Essa obra, que completa quarenta anos em 2017, já de início chamou a atenção de alguns críticos da literatura portuguesa, devido ao traço performativo do texto: exibição de rituais íntimos, encenações autobiográficas, recuperação de comportamentos renunciados, hibridação de gêneros literários, diálogo com outras artes - desenho, fotografia, cinema, pintura, música punk e rock -, além do caráter libertário evidente por meio de ressonâncias marcantes de artistas marginais contemporâneos, sobretudo o beatnik William Burroughs. Esses aspectos promoveram a abertura de novos espaços para a literatura portuguesa ao explorar as zonas periféricas da cidade, revelando encenações sexuais de homens e travestis nas noites citadinas. Em plena ditadura salazarista, em que pouca atenção era dada aos poetas, Al Berto revela também em À procura do vento num jardim d'agosto, por meio do narrador que se enuncia em primeira pessoa, as angústias da estreia em literatura naqueles tempos: "que dor é esta quando escrevo?” (AL BERTO, 2005, p. 19); “não foi fácil distinguir os jogos literários” (AL BERTO, 2005, p. 28); "não sou escritor pertencendo a qualquer turva academia de café" (AL BERTO, 2005, p. 44).

Todos esses aspectos contribuíram para que Al Berto figurasse hoje como um dos poetas mais conhecido de Portugal, em especial após ser laureado, em 1987, com o PEN Club, pela obra completa O medo (1986). Para essa obra, o autor reescreveu dois livros: À procura do vento num jardim d'agosto (fragmentos dum exílio) 1974-75 e Meu fruto de morder, todas as horas (escritas intimas), de 1980, ambos publicados pelo autor em Lis- 
boa. Em relação ao primeiro, foi retirada toda a carga alusiva aos tempos de exílio de Al Berto em Bruxelas entre os anos 1967 e 1975, ressaltando-se o foco no sujeito sem tal determinante sócio-histórico e passando a figurar como primeiro livro da obra al-bertiana. Ele já havia publicado o livro Projectos 69 (1972), além de alguns textos dispersos anteriormente que não entraram na compilação.

Na primeira série do livro em análise, intitulada "atrium", portanto o primeiro texto de sua obra completa, Al Berto escreve: "releio o que escrevi há doze anos, neste mesmo lugar" (AL BERTO, 2005, p. 12). Ou seja, pode-se especular que esse sujeito que se enuncia escreve de um átrio, pois o vocábulo de origem latina designa um espaço. No entanto, essa palavra tem outras acepções e uma delas nos interessa mais de perto para a elucidação do projeto literário de $\mathrm{Al}$ Berto. Trata-se de uma definição no campo da anatomia e significa a primeira câmara de cada lado do coração, que recebe

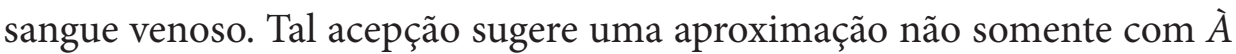
procura do vento num jardim d'agosto, mas com toda a sua obra. É desse lugar, desse interstício do corpo, que geralmente surge a escrita al-bertiana: "escutámos o que há de inaudível em nossos corpos. era quase manhã no fim deste cansaço. despertava em nós o vago e trémulo desejo de escrever [...] pelas frestas dum espaço oco perscruto o eco de meu corpo" (2005, p. 11-12). Em praticamente toda a obra de Al Berto, o sujeito que se enuncia é quase sempre um escritor a encenar algumas experiências do autor - seus biografemas. Na passagem diarística "O medo (2)", cuja data é a mesma do aniversário do autor, lê-se:
11 de janeiro
cada dia que passa escrevo menos, e o pouco que escrevo exige todo o tempo disponível. requer paixão sem partilha.
[...] hoje fiz trinta e seis anos. acabaram-se algumas coisas na minha vida, sinto isto, apesar de ainda não perceber cla- ramente o quê. estou certo que a juventude não recomeça nunca, nem terá início hoje. habituo-me à grande desolação dos dias.
diz o horóscopo que os capricórnios têm uma velhice feliz. a velhice, dizia Céline, é um sobejo da vida.
escasseia o tempo na tentativa de vislumbrar algum sossego. escrever, passar a vida a escrever, para quê? (2005, p. 359).

\section{ALBERTO E AL BERTO: EU SOU UM OUTRO OU QUALQUER COISA DE INTERMÉDIO}

Talvez possamos dizer que, para haver o deslocamento do indivíduo real (o autor, cidadão civil) para o fictício (encenação literária), Alberto Raposo Pidwell Tavares tenha criado um outro nome para assinar seus textos - Al Berto.

O meu nome surge separado em dois, porque quando eu resolvi escrever achei que era muito importante para mim pessoalmente. Houve uma maneira de estar na vida que mudou, 
então eu cortei o meu nome ao meio como quem separa algo que deixa para trás e vai para frente. Houve uma descida aos infernos comigo mesmo (AL BERTO, 1988, p. 111).

Em seu primeiro livro, Projectos 69, o poeta assina Alberto Tavares, ${ }^{2}$ mas já em $A$ procura do vento num jardim d'agosto ele crava a sua nova "identidade", estranhamente grafada: Al Berto. Alberto corta os sobrenomes - Raposo Pidwell Tavares - e como se ainda não bastasse, ele opta por fazer uma cisão no próprio nome - $\mathrm{Al}$ Berto -, correspondente também à fragmentação textual de sua obra. Segundo a concepção de Gérard Genette, o nome do autor é um paratexto importantíssimo para expansão e divulgação da obra, pois é a partir dele, impresso na capa do livro, que o leitor primeiro se relaciona. "O fato de o autor real "assinar" sua obra com um nome que não é, ou não exatamente, ou não integralmente, seu nome legal" caracteriza seu "pseudonimato" (GENETTE, 2009, p. 48).

Esse corte sugere associações com o corpo errante, sem família, que perpassa a sua escrita, predominantemente em primeira pessoa, propondo uma torção nos limites entre o eu e o outro: "eis a deriva pela insónia de quem se mantém vivo num túnel da noite. os corpos de Alberto e Al Berto vergados à coincidência suicidária das cidades" (AL BERTO, 2005, p. 64). Esse trecho de "atrium", comumente apontado pela crítica, não foi escrito quando de sua primeira edição, mas somente doze anos depois, na primeira elaboração e publicação de $O$ medo. Nesse momento, o autor já está inteiramente consciente de seu projeto literário, para o qual, então, lança luz em direção ao seu nome próprio, potencializando modos de leitura.

A respeito desse curioso nome, pode-se acrescentar ainda que uma das acepções da partícula al na língua portuguesa refere-se a um pronome antigo usado no século XIII que significa uma outra pessoa, alguma coisa, outra coisa. Ao considerarem-se esses novos sentidos ao pé da letra, chega-se a novas interpretações do nome do autor por meio das seguintes variantes: Outro Berto e Algum Berto. No entanto, essas mesmas variantes coexistem em uma mesma entidade, observadas, por exemplo, nas palavras do escritor que trabalha em seu ofício para nomear o mundo perscrutando a revelação das (antigas) palavras:

Aquele que me habita, e escreve, vive algures numa espécie de treva. Quase nada sabe da sua própria escrita. Menos ainda falar dela. Sabe, apenas, que por instantes uma incandescência terrível cresce dentro de si, ergue-se, nomeia as coisas e o mundo, apaga sombras, revela os ossos muito antigos das palavras... de resto, mais nada (AL BERTO, 2000, p. 57).

O morfema al curiosamente designa ainda um substantivo antigo em língua portuguesa, cujas acepções são densamente presentes na poética al-bertiana: o resto, o mais, a sobra. Por vezes, o próprio sujeito (e/ou sua escrita) é colocado no mesmo patamar desses vocábulos-vestígios - "nós somos os dejectos a delinquência o veneno o lixo os gases as substâncias" (AL BERTO, 2005, p. 124). Salsugem, um dos títulos de seus livros, reporta- 
-se, para além do que é salso, salgado, aos detritos que flutuam no mar ou que sobejam pelas praias e pelas beiradas dos portos. Por outro lado, a nossa língua portuguesa, herdeira de longa passagem do mundo árabe por terras ibéricas, incorporou o artigo definido al como raiz de muitos vocábulos, ou seja, como identificação básica de um grupo de palavras, por suas semelhanças gráficas, como em alfândega, alfarrábio, álcool, alquimia, alcova e alcorão. ${ }^{3}$ Dessa forma, esse artigo acresceria à constituição da alcunha do poeta um outro modo: $O$ Berto, cuja singularidade é terminantemente manifesta pelo artigo definido, também alcança modos conflitantes, pois o excesso da unidade (o $\mathrm{um}$ ) talvez seja coexistente à sua multiplicidade. Afinal de contas, o fato de o autor inscrever seu pseudônimo traz sempre mais um componente no horizonte da recepção.

A fantasia do leitor acerca do pseudônimo deixa, portanto, de ser uma simples especulação de tipo mais ou menos mimológico [...] a partir do momento em que a verdade desse patronímico é revelada por meio de um paratexto mais distante, de uma informação biográfica, ou mais geralmente da fama. [...] Acho apenas que a revelação do patronímico faz parte da notoriedade biográfica que está no horizonte, próximo ou longínquo, da notoriedade literária (a das obras em si), quero dizer: que a espera no final das contas ou que a envolve como um halo (GENETTE, 2009, p. 49-50).

Para a recepção crítica brasileira de Edgard Pereira, o nome de $\mathrm{Al}$ Berto é uma reelaboração, de certa forma, dos heterônimos Alberto Caeiro e Álvaro de Campos, de Fernando Pessoa (PEREIRA, 1999, p. 132). Para o lusitano Joaquim Manuel Magalhães, no seminal e importante ensaio sobre Al Berto, de 1981, esse nome é "um tanto kitsch". Em Al Berto, a eliminação dos sobrenomes e a quebra do seu nome, somando-se a sua obsessão por meio do "mínimo de tinta dentro da palavra" (AL BERTO, 2005, p. 579), parecem mesmo remeter à imobilidade a que o poeta almeja alcançar: ao silêncio sem quaisquer rastros de identidade, como expresso especificamente no trecho diarístico "O medo (2)": "escrevo o menos possível. quase não gesticulo. mexo-me o absolutamente necessário. é preciso chegar ao zero, ao silêncio e à imobilidade" (2005, p. 375). Mas não sendo isso possível, o poeta se instrumentaliza do trabalho com as letras para inventar um Outro, reinventando-se - "escrever no limite do dia, preparar-me para a noite, despertar em mim um nome, inventar-te" (AL BERTO, 2005, p. 375). Não seria infundado supor que, por meio dessa rarefação do nome e do meticuloso trabalho com as letras à maneira da figura de Kapa (letra K) de À procura do vento num jardim d’agosto: "sou tudo e não sou nada. [...] Kapa renasce e reflecte-me" (AL BERTO, 2005, p. 50).

Assim, o ato escritural se justapõe (escritor-personagem-autor), "porque onde termina o corpo deve começar/ outra coisa outro corpo" (AL BERTO, 2005, p. 543). Toda a sua escrita converge para a estetização de Alberto Raposo Pidwell Tavares em Al Berto, compondo uma obra de cunho especular (uma existência de papel), altamente narcísica, como bem 
apontou Fernando Pinto do Amaral (1991), ao afirmar que o poeta exibe ostensivamente marcas de sua identidade e expõe o próprio rosto nas capas dos livros. Mas esse narcisismo

[...] não se resume, para nosso teórico desconcerto, às capas em que se expunha ou às entrevistas em que, com uma obstinação eloquente, falava interminavelmente de si próprio [...] é a partir desse outro texto que é o corpo que devem ser entendidas as "poses" [e] os ímpetos "confessionais". [...] Não se pense, contudo, que preterir a literatura em favor da vida seja uma escolha fácil, feliz e definitiva. Talvez se afigure desnecessário repetir, com Rimbaud, que "la vraie vie est absente", mas lembrarei em todo o caso, que essa impertinente vida continuou a ser para $\mathrm{Al}$ Berto uma pergunta sem resposta. [...] Felizmente, não me cabe a mim responder. Foi ainda $\mathrm{Al}$ Berto quem um dia gritou: "nada de literaturas". Mas nada mais ficou, para além disso (FREITAS, 1999, p. 91-94).

Ressalte-se que o sujeito que se enuncia em $\grave{A}$ procura do vento num jardim d'agosto não é um cidadão comum que escreve sem maiores pretensões literárias. Ele sofre da "terrível ânsia do primeiro livro" (AL BERTO, 2005, p. 28). É curioso observar que tanto o narrador quanto o autor estão estreando na literatura. Portanto, tal sujeito, ao relatar suas histórias, deixa pistas (rastros-restos) da concepção da escrita performativa de Al Berto.

\section{"ISTO NÃO É UM ROMANCE"}

Um ponto importante a ser abordado em $A$ procura do vento num jardim d'agosto (fragmentos dum exílio) é a hibridação do gênero textual, ou sua narratividade performática. A forma desse livro é bastante similar a Meu fruto de morder, todas as horas (1980), que juntamente com Lunário (1988) e O anjo mudo (1993) são os mais diferenciados do restante da obra al-bertiana por apresentarem uma gama imensa de personagens. Ainda que se possa dizer que Alaíno, Nému ou Zohía, personagens tanto de $\grave{A}$ procura do vento num jardim d’agosto quanto de Lunário, não são propriamente personagens, mas meros desdobramentos especulares do sujeito da enunciação - um escritor -, esse fato não caracteriza essa obra como poética. Pelo menos mais dois aspectos contribuem para que o leitor trate $\bar{A}$ procura do vento num jardim d'agosto como pertencente ao gênero poesia. Um deles é relativo à recepção: o nome de $\mathrm{Al}$ Berto está invariavelmente ligado à lírica, e este é o primeiro livro que integra a obra completa $O$ medo, denominada como "Trabalho poético". O outro fator é relativo à própria escrita: a fragmentação textual e a afirmativa instigante de que o que se escreve não é um romance:

é Nervokid, é Tangerina ou Nému, perdendo-se na sombra do restaurante. ele ou ela mastiga o bife, pela janela entra o reflexo da lua sem pálpebras, desenha-lhe a testa, o nariz, a 
boca afiada de Tangerina. espio por entre as cadeiras os pés de Nervokid, nus, pequenos, procurando a frescura avermelhada do tijolo. abrem-se, fecham-se tremelicando, as pálpebras exaustas de Tangerina. não, não vou falar de Nému, nem dela. isto não é um romance (AL BERTO, 2005, p. 15-6).

Como se percebe, o sujeito da enunciação é um escritor; e ao negar que seu texto é um romance, coloca o mesmo num horizonte romanesco, ou pelo menos sugere tal investigação. E continua:

às vezes, escrevo coisas assim, unicamente para ter o prazer de me reler. saborear o que sobejou da noite, duma realidade qualquer talvez para avaliar o meu próprio lixo e amar-me um pouco mais. outras vezes, modifico essa realidade, emendo-a, sublimo-a, rasgo-a, expulso-a da memória (AL BERTO, 2005, p. 16).

Nessa passagem, o narrador revela o modo pelo qual concebe sua escrita: rasga e emenda fragmentos de uma realidade qualquer que se passa com ele, referenciando ao método cut-up do escritor beatnik William S. Burroughs (1914-1997), um dos principais expoentes da beat generation dos Estados Unidos. Esse autor norte-americano é presença marcante em À procura do vento num jardim d'agosto; pois, além da epígrafe na primeira edição (1977), ${ }^{4}$ Burroughs é homenageado, surgindo também como personagem numa das séries do livro, "Teus dedos de noite açucarada":

ultrajosamente vestido de sensuais rasgões e de couro. o rosto escondido nuns óculos de noite. titubeando invadiu a boda do palco. os sexos crisparam-se frágeis. ele ondeia o corpo acaricia o microfone preso nas mãos perto da boca. depois desequilibra-se e pende para a frente. Willy B. mostra o sexo distendido e mole (AL BERTO, 2005, p. 36).

Al Berto não demarca com nitidez os territórios entre prosa e poesia (AMARAL, 1991, p. 119). Mas, em À procura do vento num jardim d’agosto, com maior atenção verifica-se que sua linguagem é predominantemente narrativa; embora ocorra a hibridação dos gêneros, ainda não se caracteriza como um texto poético, porque essa obra apresenta as três categorias fundamentais do gênero romanesco: tempo, espaço e sujeito; ou seja, duração, localização e voz. Na contemporaneidade, essas categorias são flexíveis e não mais estanques como no romance tradicional, segundo o modelo realista, que se caracteriza, em muitos casos, por uma escrita linear, cuja narrativa apresenta princípio, meio e fim da ação. Ao se comparar o livro À procura do vento num jardim d'agosto com esse modelo, pode-se afirmar que ele não é mesmo um romance, pois não segue tal linearidade. No entanto, a narrativa sustenta-se fundamentalmente, e aqui se inclui, sem dúvida, o texto al-bertiano, "no desejo de que a legibilidade se dê via reconhecimento (o que, naturalmente, pode incluir o fator estranhamento). O gesto narrativo é, pois, sempre comparativista, já que coloca em diálogo noções de tempo, espaço e sujeito" (SANTOS, 2002, p. 183). Um texto poético pode prescindir dessas categorias, pois é a matéria da palavra que está em primeiro plano; o texto narrativo, porém, não abdica delas. 
Al Berto utiliza outros recursos diferentes do romance tradicional para sustentar a narrativa. Os espaços são múltiplos: “opiáceo cenário dum rock'nd roll suicídio sulcando a noite/ geométricos desertos/ procurei-te nos escombros duma guerra antiga/ no buraco de uma bala/ nos escombros do metropolitano" (AL BERTO, 2005, p. 63); o sujeito, sobretudo o sujeito narrador, se desdobra em outros personagens: "Kapa renasce e reflecte-me" (AL BERTO, 2005, p. 50); e o tempo está mais no plano psicológico do que no plano histórico, pois

trata-se do chamado tempo psicológico, que, configurado pelas sensações e impressões do sujeito, opera uma ruptura na sucessão cronológica. É um tempo marcado por experiências individuais, diretamente relacionado com o fluxo de consciência dos sujeitos ficcionais, imune à regularidade geométrica do tempo histórico; é, ainda, um tempo da memória, porque obediente a associações mentais que escoam incessantemente e assinalam a transformação e o desgaste que sobre o sujeito provocam a passagem do tempo histórico e as experiências vividas. (SANTOS; OLIVEIRA, 2001, p. 57).

Em grande parte, os episódios são narrados no tempo presente, e variadas vezes intercalados por lembranças, restos de histórias pretéritas. Essa inconstância temporal, mostrada com a oscilação entre os tempos eventualmente o futuro -, causa certa estranheza:

o gato dorme, dorme em seu regaço de morta como um pião de luz e de pêlos. o gato pouco se importa que estejamos vivos ou mortos

um dia, Zohía disse: Nós já não andamos de Rolls Royce, agora jogamos ao flipper e metemos ácidos e matamo-nos num tilt! bêbados cantarolamos obscenidades de top ten americano. Deixámos, pura e simplesmente, de usar cuecas.

ouço o vento gelado de Bruxelas recolhendo-se em sua orelha mística. à sua volta remexem-se sonhos coloridos do México, panteras brancas de cocaína, o Vulcão de Lowry. e mais tarde, muito mais tarde, ela hibernou nos contornos de nossos corpos abandonados. Zohía das Noites Lentas, Zohía dos Segundos de Fogo!

$\mathrm{O}$ gato adormeceu em cima da máquina de escrever (AL BERTO, 2005, p. 21).

O livro À procura do vento num jardim d'agosto pode ser considerado uma narrativa, mesmo que o reconhecimento se dê via estranhamento - na interação do leitor com a obra -, devido à fragmentação da linguagem com forte pendor lisérgico e ao clima insólito dos fatos que se sucedem em meio a conturbadas imagens urbanas:

PANORÂMICA SOBRE A CIDADE EM CÉU DE SERINGAS TRANSPARENTES: no centro do sismo está o jardim de borboletas/ estranho rosto de asas queimadas estendido por cima da pálpebra/ boca seca e aberta/ / petrifica um desejo de esperma/ treme o corpo ao sugar a seiva da luz/ uma lâmina 
corre vertiginosa pela ausência doutro corpo/ nos dedos um caroço estelar/ pulsos abertos manchando a noite das cidades/ luares brancos de Tangerina/ / acorda/ sem dias e sem noites/ minuciosamente o tempo grava em mim Tangerina/ a sombra dum osso e duma laranja nas mãos (AL BERTO, 2005, p. 50).

\section{A ESCRITA PERFORMÁTICA DE AL BERTO}

À procura do vento num jardim d’agosto compõe-se de sete séries narrativas - "Atrium", "Equinócios de Tangerina”, "Teus dedos de noite açucarada", "Push here com uma polaroid", "As mãos de Kapa num jardim d’agosto", "Nota autobiográfica e stop" e "O pranto das mulheres sábias" que têm em comum um sujeito (uma voz protagonista), invariavelmente um escritor, relatando o ato de escrita como se fosse um diário de viagem: "ainda tenho resmas de papel para escrever. a viagem está segundo a segundo a ser registada. quando faltar papel escreverei sobre a pele do viajante" (AL BERTO, 2005, p. 15). Essa aventura é contada, por vezes, simultaneamente aos fatos: "escrevo o que me vai acontecendo. vejo tudo. escondo-me do lirismo dos outros e vivo num romance de cortinas brancas" (AL BERTO, 2005, p. 19).

As andanças desse sujeito são por urbes europeias: "continuo a caminhar de cidade em cidade sem saber para onde vou. donde venho" (AL BERTO, 2005, p. 42). Algumas vezes, esse nomadismo faz com que ele deixe o ofício de escritor, devido aos percalços da viagem: "nunca consegui escrever com continuidade, a vida não deixou, foi caótica, um frenesi de itinerários, peregrinações, travessias, transumâncias, paixões, fugas" (AL BERTO, 2005, p. 20). Em outro momento ele se lamenta e diz: "certas coisas apagam-se antes que eu as consiga transformar em escrita" (AL BERTO, 2005 , p. 34). O texto, então, vai-se concretizando com fragmentos do cotidiano, num ritmo acelerado e alucinógeno.

Em outras passagens, as cenas se passam sob uma perspectiva multifacetada: "sou aquele que se transmuda em milhares de máscaras e não é ninguém” (AL BERTO, 2005, p. 15). Esse sujeito se torna um agenciador de subjetividades: "claro que só posso ser um espião, um depredador de noites e solidões alheias" (AL BERTO, 2005, p. 15). Devaneio e realidade confundem-se, os personagens são frutos de uma condensação de fantasias: "Nervokid cresceu por uma noite de insônia, saltámos as grades das palavras, de mãos dadas, levantámos os pés do chão e vogamos" ( $\mathrm{AL}$ BERTO, 2005, p. 24). À medida que o sujeito narra suas vicissitudes, vão surgindo outros personagens: "Nervokid nasceu da insónia, Tangerina do silêncio da Alba, e eu sou a fusão viva dos dois" (AL BERTO, 2005, p. 24). Como conceber que dois personagens possuam um só corpo? As angústias, aventuras e fantasias desse narrador é que são relatadas durante seu percurso errático. Desse modo, a existência dos personagens apenas ratifica a 
ênfase no sujeito como corpo central da narrativa, pois eles surgem como uma extensão do narrador para realizar as ações deste, sobretudo para ressaltar a encenação de sua escrita:

Tangerina meu corpo-altar! / [...] Tangerina das cidades costeiras, Tangerina das noites de viagem, meu navio à deriva. Nervokid, escuta, escuta a cidade que se prolonga calcinada até onde adormeceu Tangerina. / nos dentes amachuco a folha de papel escrita, mordo noite adiante o ombro decotado e literário de Tangerina. invento-o e mordo-o, como sempre fiz, esfrego o sexo nas palavras, meto-lho nas mãos sujas de literatura, viro-a enrabo Tangerina ainda mal acordada no fundo da memória. mordo-lhe a nuca, mordo-a até não sentir em mim absolutamente mais nada (AL BERTO, 2005, p. 18).

Nesse livro, palco do literato, acentua-se uma das características mais singulares da escrita al-bertiana: o caráter de performer do autor. Todo o texto converge para o desdobramento especular do sujeito da enunciação em seus personagens. Por essa especificidade, somada ao traço autobiográfico em sua obra, como então discernir tal escrita? O conceito de "narrativa performática” trabalhado pela pesquisadora argentina Graciela Ravetti, parece assaz adequado a esse propósito, pois, através dele, é possível abarcar as instâncias fundamentais que apoiam a escrita de Al Berto - a encenação do próprio autor; a maneira como o sujeito se enuncia; e, claro, o meio em que se representam tais aspectos, qual seja o texto, em sua forma e conteúdo -, pois a particularidade de tal narrativa é definida por

tipos específicos de textos escritos nos quais certos traços literários compartilham a natureza da performance, recorrendo à acepção desse termo, em sentido amplo, no âmbito cênico e no político-social. Os aspectos que ambas noções compartilham, tanto no que se refere à teatralização (de qualquer signo) e à agitação política, implicam: a exposição radical do si-mesmo do sujeito enunciador assim como do local de enunciação; a recuperação de comportamentos renunciados ou recalcados; a exibição de rituais íntimos; a encenação de situações da autobiografia; a representação das identidades como um trabalho de constante restauração, sempre inacabado, entre outros (RAVETTI, 2002, p. 47, grifos da autora).

Para delinear em Al Berto os contornos dessa narratividade, é pertinente ratificar que o autor, já na década de 1970, ainda que para um círculo restrito de pessoas, devido ao caráter marginal de sua obra, foi um nome importante no cenário artístico português. Ele esteve sempre ligado à política cultural, exercendo alguma função nessa área. Em Bruxelas, 1969, Al Berto funda, com alguns amigos (artistas plásticos, escritores e fotógrafos), a Associação Internacional Montfaucon Research Center. Em 1972, estagia como animador cultural em Hainaut, na Bélgica; durante esses anos, organiza e participa de exposições de desenho e pintura. Entre 1976 e 1980, foi editor de seus livros e também lançou novos autores. De 
1981 ao final de 1985, exerceu a atividade de animador cultural da Câmara Municipal de Sines. A partir de 1987, integra a Comissão Instaladora do Centro Cultural Emmerico Nunes, em Sines, assumindo o cargo de coordenador. Entre setembro de 1990 e setembro de 1991, participa da assembleia de fundação da cooperativa do CCEN, integrando a primeira direção. Entre maio de 1992 e janeiro de 1994, preside o Emmerico Nunes. Al Berto sempre foi atento às expressões artísticas de seu tempo, seja na literatura, seja nas artes plásticas e visuais, refletindo-as em sua escrita performática. É pertinente, pois, ressaltar dois aspectos de sua experiência de vida que repercutem diretamente em sua obra: por um lado, suas vivências em ambientes marginais europeus, pois "escreve-se como um performer quando as imagens e os objetos criados pela ficção se entremesclam com algo de pessoal" (RAVETTI, 2002, p. 63) e, por outro, a estreita ligação com a fotografia, o desenho e a pintura.

O primeiro desses aspectos refere-se aos tempos de expatriação do autor na Bélgica quando da escrita de À procura do vento num jardim d'agosto (fragmentos dum exílio 1974-75), assim como o sujeito que se enuncia nessa obra, também vive em deambulações pela Europa. Eduardo Pitta conta, em seu texto intitulado "Al Berto", que foram "anos negros" vividos pelo artista em Bruxelas - diferentemente da imagem romantizada de uma "cenografia hippie (versão Europa central) de noitadas, putos louros, copos, charros, chutos e travestis. Não foram isso desse modo light, quero eu dizer" (PITTA, 2004, p. 13). Al Berto viveu realmente as "noitadas" da capital belga e de outras cidades europeias - e foi um importante autor a revelar à literatura portuguesa os acontecimentos que se passavam nesses ambientes marginais, abordando reiteradamente em seus textos os guetos onde circulavam as drogas e a prostituição masculina. Para Joaquim Manuel Magalhães, o autor surgiu

como um ataque por todas as vias - droga, sexo, loucura, jogo, magia. Um fluxo de revelação, pela porta entreposta das "viagens", dos "travestis", dos "putos", das "bichas" e da exaltação do amor e do desejo, desencadeia um modo diverso de enfrentamento da ocupação maioritária dos impulsos, das práticas, da vida (MAGALHÃES, 1981, p. 268).

A partir de sua experiência, Al Berto evidencia para Portugal, para "um país onde até o simplesmente erótico é por alguns considerado ofensivo" (ROCHA, et al., 2001, p. 15), os acontecimentos noturnos das cidades, aqueles que ocorrem entre quatro paredes dos quartos de pensão, nas ruas, nos bares, nos portos e nas danceterias.

O segundo dos aspectos é o caráter interartes de sua obra - fruto de sua formação em artes plásticas -, o que valida a conceituação de que a sua escrita é mesmo performática, porque também "escreve-se como performer quando a palavra consegue dar um salto a outras linguagens, a imagens geradas por outras leis e o diálogo que se instala faz uma alquimia que reforça os sentidos" (RAVETTI, 2002, p. 63). Em sua narrativa, Al Berto dialoga 
com outras artes, como o desenho, a pintura, a fotografia e o cinema. Vale a pena lembrar que, na primeira edição de $\grave{A}$ procura do vento num jardim d’agosto, o desenho estampado na capa é de sua autoria, além de uma encenação fotográfica entre as páginas do livro.

Vejam-se alguns outros exemplos de como se manifestam as demais artes nessa obra de $\mathrm{Al}$ Berto. Em relação à pintura, o personagem-narrador relata que ele era um pintor, assim como o autor:

pintava sem cessar, pintava até deixar de pintar, as imagens fixas aborreciam-me, a pintura também. e um dia ofereci o material de pintura e dormi descansado, tinha ludibriado o destino que me haviam preparado. o sexo acordou húmido, angustiado, silencioso. houve silêncios inexplicáveis no sexo e na alma. mas não voltei a pintar. o céu estava sulcado de rostos, túmulos, máscaras de água, inscrições premonitórias. chegara o momento de começar a escrever. perscrutava as nuvens vermelhas, os sóis que gemem e caem com estrondo sobre o peito. já não conseguia sentir, só escrevia (AL BERTO, 2005, p. 27-28).

O sujeito da enunciação abandona "as imagens fixas" da pintura; porém, continua ele: "começaria a escrever sempre em quadricromia" (AL BERTO, 2005, p. 28). Percebe-se na obra um sem-número de cores ao serem descritas as imagens urbanas: "máquinas amarelas" (AL BERTO, 2005, p. 50), "formas de laranja de pássaro de peixe de azul" (2005, p. 50), "um vapor lilás" (AL BERTO, 2005, p. 29), “crianças azuis” (AL BERTO, 2005, p. 22). Até mesmo alguns substantivos abstratos têm cores: "desejos coloridos" (AL BERTO, 2005, p. 16) e "morte branca" (AL BERTO, 2005, p. 50). Tangerina, um dos personagens principais, também evoca uma cor. Toda essa construção pictórico-literária, associada também a recursos cinematográficos - cortes de cenas, mudança de foco, indicativos de voz em off-, é uma tentativa de capturar as imagens justapostas de um cotidiano disfórico e transferi-las para o texto, retratando o "delírio espesso e fragmentado do infernal filme da cidade” (AL BERTO, 2005, p. 61). As histórias não têm duração nem profundidade; são flashes de cenas que se sucedem, como neste fragmento:

no écran em technicolor notícias de última hora:

EXPLOSÃO VIOLENTA NO YORKSHIRE ESTA NOITE INTERVENÇÃO DAS FORÇAS DA ORDEM E AS PROSTITUTAS TAMBÉM SÃO FILHAS DO SENHOR OCUPAM AS IGREJAS EM BREST ARDE ESTE MISTÉRIO DAS CIDADES JUNTO AO MAR A VÍTIMA FOI DESCOBERTA EMBALSAMADA DENTRO DUMA SEBE DE MADRESSILVAS A BRIGADA DE ESTUPEFACiENTES DESMONTOU MAIS UM (AL BERTO, 2005, p. 20).

Em síntese, o que Al Berto faz, para além de representar, é mostrar o movimento e a visibilidade tais como operam dialogicamente na errância do sujeito que se enuncia - personagem e eixo central de sua narrativa. Essa 
forma de escrita, a que se atribuiu aqui o conceito de "narrativa performática", permite ao autor a liberdade de encenar situações autobiográficas, dialogar com outras artes e transitar entre os gêneros literários e entre os tempos, tanto em termos da releitura de determinadas tradições literárias - Burroughs, por exemplo -, quanto em relação à estruturação temporal da narrativa, haja vista que em $\grave{A}$ procura do vento num jardim d'agosto não há uma anterioridade através da qual se possa estabelecer uma relação de causa-efeito, nem sequer uma verossimilhança espaço-temporal dos personagens. Ao escrever, o autor liberta-se da unidade e da linearidade, passando a trilhar o cruzamento dos tempos, no qual o instante surge como aquele momento em que futuro, presente e passado se unem num ponto.

\section{REFERÊNCIAS BIBLIOGRÁFICAS}

AL BERTO. Projectos 69. Lisboa: Assírio \& Alvim, 2002 [1972].

. À procura do vento num jardim d'agosto (fragmentos dum exílio) 1974-75. 1ª edição. Alberto R. Pidwell Tavares, Editor, 1977.

. Entrevista (Al Berto). Revista de imprensa. Lisboa, 1988, p. 111. . Lunário. Lisboa: Assírio \& Alvim, 1999 [1988].

. O anjo mudo. Lisboa: Assírio \& Alvim, 2000 [1993].

. O medo. $2^{\text {a }}$ ed. Lisboa: Assírio \& Alvim, 2005.

AMARAL, Fernando Pinto do. O mosaico fluido. Lisboa: Assírio \& Alvim, 1991.

FREITAS, Manuel de. A noite dos espelhos - modelos e desvios culturais na poesia de Al Berto. Lisboa: Frenesi, 1999.

GENETTE, Gérard. Paratextos editoriais. Trad.: Álvaro Faleiros. Cotia/SP: Ateliê, 2009.

GUIMARÃES, Gustavo Cerqueira. Al Berto, poeta-editor: as margens da poesia. Estudos Linguísticos e Literários. Salvador (Instituto de Letras da UFBA), n. 51, p. 1-18, 2015.

MAGALHÃES. Joaquim Manuel. Os dois crepúsculos. Lisboa: A Regra do Jogo, 1981.

PEREIRA, Edgard. Portugal: poetas do fim do milênio. Rio de Janeiro: 7 Letras, 1999.

PITTA, Eduardo. Metal fundente. Vila Nova de Famalicão: Quase Edições, 2004.

RAVETTI, Graciela. Narrativas performáticas. In: ; HARBEX, 
Márcia (orgs.). Performance, exílio, fronteiras: errâncias territoriais e texturas. Belo Horizonte: FALE/UFMG, 2002, p. 47-68.

ROCHA, Anabela et al. $1^{a}$ Antologia de literatura homoerótica portuguesa. Lisboa: Korpus/Opus Gay, 2001.

SANTOS, Luis Alberto Brandão. Teoria do corpo na literatura brasileira contemporânea. In: DUARTE, Rodrigo et al. (Org.). Kátharsis: reflexos de um conceito estético. Belo Horizonte: C/Arte, 2002, p. 182-187.

SANTOS, Luis Alberto Brandão; OLIVEIRA, Silvana de. Sujeito, tempo e espaço ficcionais. São Paulo: Martins Fontes, 2001.

\section{Recebido para publicação em 15/02/2017 \\ Aprovado em 17/04/2017}

\section{NOTAS}

1 Mestre e Doutor em Estudos Literários pela Universidade Federal de Minas Gerais, com pesquisas sobre a espacialização do sujeito em Al Berto. Graduação em Psicologia Clínica e Letras (Licenciatura Plena em Português) pela PUC-Minas. Atualmente, é pesquisador de pós-doutorado junto ao Programa de Pós-Graduação em Estudos Literários da Faculdade de Letras da UFMG.

2 Maior aprofundamento sobre Projectos 69 e os primeiros anos de publicação do Al Berto, cf.: GUIMARÃES. Al Berto, poeta-editor: as margens da poesia. Estudos Linguísticos e Literários. Esse trabalho explora sistematicamente a primeira década da poesia de $\mathrm{Al}$ Berto, período compreendido entre 1972 a 1982. Destacam-se quatro fatores de sua obra que se relacionam: a recepção (fortuna crítica); a face imagética; o processo marginal das edições - Projets 69, À procura do vento num jardim d'agosto, Meu fruto de morder todas as horas, Mar-de-leva, Dix adresses avant de disparaître e Trabalhos do olhar-; e, por último, o período de exílio em Bruxelas, pouco explorado pela crítica, no qual o poeta se tornou integrante do coletivo de artista intitulado "Montfaucon Research Center".

3 Interessante constatar en passant que a epígrafe de À procura do vento num jardim d’agosto deriva da tradição do reino de Alá, do livro sagrado dos mulçumanos. A seleção de $\mathrm{Al}$ Berto condensa em poucas palavras os mitológicos temas do desejo, da nudez e da transgressão, tão caros a sua obra: "Eles comeram (do fruto) da árvore, e a sua nudez apareceu-lhes, puseram-se a bordar roupa de folhas do paraíso. Adão desobedeceu ao seu Senhor e extraviou-se. / Alcorão, XX, 119” (1977, p. 15).

4 "Une meute de garçons sauvages peut couvrir cinquante miles par jour. Une poignée de dattes et un morceau de sucre naturel et une tasse d'eau leur permet de bouger ainsi. Et le bruit qu'ils font juste avant d'attaquer... eh bien j'en ai vu un fracasser une serre à cinquante mètres... Que je vous montre comment les garçons sauvages attaquent”. W. S. Burroughs, Les garçons sauvages, un livre des morts. In: AL BERTO, À procura do vento num jardim d’agosto (fragmentos dum exílio) 1974-75. 1ª edição. Alberto R. Pidwell Tavares, Editor, 1977, p. 20. 